\title{
歯牙エナメル質の被削性に関する研究
}

第 2 報・超音波加工法によるエナメル質の被削性について

\author{
加 藤 仁 市
}

\section{Studies on Effects of Tooth Enamel Being Ground}

Part 2. On Effects of Tooth Enamel Being Ground with Ultrasonic Work Method

\author{
Niichi Katoh
}

\section{I. 緒 論}

最外表の組織であるエナメル質は, 歯牙が口腔内で機 能を営む時, さまさまな環境に直接さらされるので, こ れを正常に維持, 管理することは重要である.

またう蝕に罹患した歯牙を修復する際に, 石灰化組織 および諸器官に為害作用を与えることなく，䍜患茵質の 除去, 予防拡大および修復物へ至適形態を与える形成を 行うことも重要である ${ }^{1-3)}$.

歯牙の研 (切) 削は, 歯牙形成における最適条件の検 索を最終目的とし, 各種の機械と工具が考案, 開発され た ${ }^{4,5)}$. したがつて最適条件については, 歯牙, 工具, 機 械の三者間に引き起こされる現象を詳細に追求する必要 があり, 研削における研削能率 ${ }^{6,7)}$, 歯牙の温度上昇 ${ }^{8,9}$, 工具の振動, 音響により起こる生体人の影響等 ${ }^{10,11)}$ につ いての研究がある.

著者は歯牙研削の最適条件をエナメル買の破砕状況か ら判定することを目的とし，エナメル質の組織的形態の 変化から，その被削性の検討を行うことを計画してい る.

エナメル質微細構造の形態観察による研究は, 光学顕 微鏡 ${ }^{12 \sim 14)}$, 電子顕微鏡 ${ }^{15 \sim 18)}$ により, 腐蝕液, 腐蝕時間に よる影響，およびェナメル小柱走行に対する種々の角度 からの検討等, 種々の条件における観察 ${ }^{1921)}$ がエナメル 質表層からエナメル質・象牙質境まで詳細に報告 ${ }^{22}$ され

新渴大学歯学部歯科補緅学第 1 教室 (主任: 石岡 靖教授) Department of 1st Prosthetic Dentistry School of Dentistry, Niigata University (Director Prof. Kiyoshi Ishioka)

昭和 50 年 2 月 3 日受付
ている.

エナメル小柱の走行が部位により相当複雑で, かつ石 灰化の異なる部分を含んでいることを考虑すると, 内部 の関連によつて被削性に相違が生ずることが予測され る. この場合遊離碰粒を使用する超音波加工法 ${ }^{23)}$ は, 被 削物の局所における被削性を検討する目的に適している と判断し, 被削性の均一であり嗍硅酸ガラスを対象群と して歯牙の被削性, 使用砥粒の粒度の影響を検討し, 第 1 報として報告した ${ }^{24)}$.

エナメル小柱に対する加工方向 (長軸, 短軸) と加工 圧 $(50 \mathrm{~g} \sim 1,200 \mathrm{~g})$ の組み合わせにより, 種々超音波加 工を行つた結果について, 走査型電子顕微鏡による観 察, 加工速度および加工面のあらさの検討を行つたの で，第 2 報として報告する.

\section{II. 研究方法}

1. 被削材と碴粒粒度の違いによる加工面の検討.

2. 加工圧と加工方向 (エナメル小柱に対する) の違 いによる加工面の検討.

3. 加工圧と加工方向の違いによる加工時間の検討.

4. 加工面の表面あらさの検討.

1. について

前回の実験と同様に被削性の均一であるガラスを対象 とし， $\$ 80 ， \$ 180 ， \$ 320 ， \$ 800$ のグリーン・カーボラン ダム砥粒でエナメル質に加工を施し, 加工面を走査型電 子顕微鏡で検鏡, 比較検討した.

使用した超音波加工機は前回の実験と同様のものであ る. 加工試料は超音波洗滌器で加工面に付着している力 ーボランダム砥粒を除去し， $2 \%$ 塩酸液に 45 秒浸し腐 蝕を行つた後, 超音波洗涤器で 3 分間洗滌, 空中乾燥 
し, 真空で回転蒸着法によりカーボン・金の 2 重蒸着を 行い, 日立製作所製 SSM-2 型走査電子顕微鏡を加速電 圧 $20 \mathrm{kV}$ の条件下で検鏡し写真撮影を行った.

\section{2. について}

回転工具による歯牙被削性の検討においては，工具へ の荷重は, 回転速度に影響を与えることを明らかにし， 高速歯科切削において能率を高めるときの荷重と速度の 関係にふれ, 低速側 $(10$ 万 rpm) では荷重を増加し, 高速側（25万 rpm）では荷重を柽隇した方が有利であ るとの報告 ${ }^{25) か ゙ あ る . ~}$

超音波加工に㧍いても，加工速度に対する最適加工圧 の研究があり 23,26,27), 加工圧の違いが加工面に影響を及 ぼすことが予測され，50 g, $100 \mathrm{~g}, 300 \mathrm{~g}, 600 \mathrm{~g}, 900 \mathrm{~g}$, $1,200 \mathrm{~g}$ の加工圧で加工を行い, 加工圧の違いが加工面 に及ぼす影響について検討した。

使用した砥粒は前回の実験で加工性が優れていると判 断された

また回転工具を使用し, エナメル小柱に対し, 直角, 平 行両方向に研削を行い, その研削屑を光学顕微鏡および 電子顕微鏡での観察とX線回折の結果, 直角方向に研削 したときにェナメル小柱の破壊がより大きいとの報告が ある28).

本実験の超音波加工法は振動子の径が $1.0 \mathrm{~mm}$, 砥粒 の最大径が約 $60 \mu$ で, 加工終末時にはその大きさが数 $\mu$ 位まで小さくなることから判断して, 複雑な走行を呈 し, 組成が均一でないエナメル小柱に対しても, 選択的 に限局された部位への加工が可能と思われる。

エナメル小柱の異なる走行方向へ, 種々の加工圧で加 工を施し，その加工面の観察を行つた.

\section{3. について}

2. の実験における加工速度から, それぞれの条件に おけるエナメル質の加工性について検討を加えた。

加工速度の計測は前回の実験に使用した, 日本光電社 製 Force-displacement tranducer pick up で試料の変 位を時間と距雇の関係としてあらわした。

\section{4. について}

加工圧を $300 \mathrm{~g}, 600 \mathrm{~g}, 900 \mathrm{~g}$ としたガラス，歯牙の 超皆波加工面あらさを, 小坂式万能形状測定器 SE-3 型 を使用し，縦 1,000 倍, 横 100 倍で測定した。

\section{III. 結果と考察}

\section{1. 被削材と碈粒粒度の違いによる加工面について}

図 1，2，3，4はガラスをそれぞれ \$80，\$180，\$320，
\$800 のグリーン・カーボランダム砥粒で加工した加工 面の 1,000 倍の電子顕微鏡写真である.

被削性の均一であるガラスは砥粓が大きくなるにつ れ，加工面が粗になることが観察される.才なわち使用 砥粒の大きさは $\$ 80: 297 \mu$ ， \$800:24 $\mu$ で約 10:4:2:1の比になつており，砈粒 により形成された加工溝を計測すると， $80: 13 \mu$, \#180

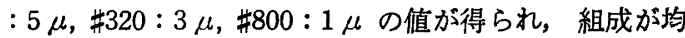
一であるガラスは砥粒の粒度により著明な影然を受ける ことが明らかである.

図 5，6 は土ナメル質を $\$ 80 ， \# 320$ で加工した加工面 の 1,000 倍の電子顕微鏡写真である. エナメル質の䂠粒 の粒度による影㗽はガラスに比較し明らかでない.エナ メル質は石灰化の異なる組織を有し，かつエナメル小柱 の走行に錯綜して複雑部分があるため, 砥粒の粒度によ る影響が組成の均一なガラスに比較して，画一的になら ず複雑な様相を示している.

\section{2. 加工圧と加エ方向の違いによる加工面について}

図 7〜12 はエナメル小柱走行の長軸方向, 図 13〜18 は短軸方向一加工压 $50 \mathrm{~g}, 100 \mathrm{~g}, 300 \mathrm{~g}, 600 \mathrm{~g}, 900 \mathrm{~g}$, $1,200 \mathrm{~g}$ でそれぞれ加工を施こした加工面の 100 倍の電 子顕微鏡像である.

この低倍の写真ではエナメル小柱の走行の違いによる 影響は著明でないが，加工圧 $50 \mathrm{~g}, 900 \mathrm{~g}, 1,200 \mathrm{~g}$ では 加工面が粗いことが認められ，また加工圧 $600 \mathrm{~g}, 900 \mathrm{~g}$, $1,200 \mathrm{~g}$ の加工面には, 超音波加工の際生じたと思われ る龟裂が認められる. また, $900 \mathrm{~g}, 1,200 \mathrm{~g}$ の加工圧に おける加工穴縁が粗である.

本加工法は一定の幅を有している工具を振動させるこ とにより, 被削材に砥粒をたたきつけてクラックを作 り,これを連続的に行つて加工を行うものである. 加工 時に砥粒は遊離しているので，加工されやすいところを 選択的に掘り進む性盺を有していて，かつ遊離砥粒によ る最初のクラック形成開始時には，遊離砥粒が被削材に 引つかかり易い, 最適加工圧が存在することが報告され ている. 最適加工压より加工圧が小さい場合は砥粒が被 削材に押しつけられる圧が小さいのでクラック形成開始 に時間を要し，また反対に加工压が大きい場合は振動子 と被削材の間に存在する砥粒の数が減少するために加工 時間が長くかかることになる。

図 19，20，21，22 は図 10，16，11，17 の同一視野の 2,000 倍の写真像である(図 19,20 は加工圧 $600 \mathrm{~g}$, 図 21, 22 は加工圧 $900 \mathrm{~g}$ ).

それぞれの写真にはエナメル小柱の破折断面とカーボ 


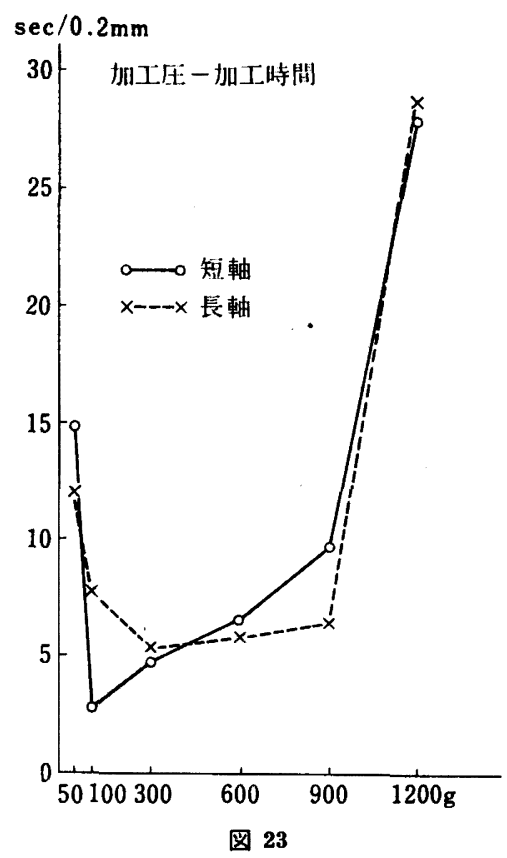

ランダム研粒による加工溝が認められ，図 19，21（長軸 方向）と図 20,22（短軸方向）の比較よりエナメル小柱 の短軸方向の加工面が長軸方向の加工面より破壊が大き いことが認められる。

回転工具を使用して, エナメル小柱に平行方向と直角 方向に研削を行って，小柱の走行と研削方向の関係を切 削屑などから検討したところ，直角方向に研削した方が エナメル小柱の破壊が大きいという報告28)があり，本実 験結果と一致している.

3. 加工圧と加工方向の違いによる加工時間について 超音波加工汸ける加工圧を $50 \mathrm{~g}$ から $1,200 \mathrm{~g}$ の範 囲で変化させて，エナメル小柱長軸, 短軸それぞれの加 工方向における加工速度を計測し，歯牙の被削性の検討 を行つた (図 23).

加工圧 $1,200 \mathrm{~g}$ では約 30 秒， $50 \mathrm{~g}$ では約 $12 \sim 15$ 秒 となり, 他の荷重に比して時間が長く, $300 \mathrm{~g}$ と $600 \mathrm{~g}$ では 5〜6 秒と短時間に加工が行なわれた.

本加工法においては加工速度が最大になるような最適

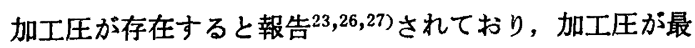
適加工压より大きくなつても，小さくなつても加工速度 が低下することが示摘されている.本データにおいても その傾向が明らかであつた.

加工速度がはやい加工圧 $300 \mathrm{~g}$ でエナメル小柱の長, 短軸方向へそれぞれ 30 回加工した加工時間を，表 1 の
表 1 エナメル小柱走行一加工速度の検定

(加工压 $300 \mathrm{~g}$ )

\begin{tabular}{l|c|c|c}
\hline & 長 軸 & 短 軸 & \\
\hline $\mathrm{A}<\overline{\mathrm{x}}$ & 20 & 16 & 36 \\
\hline $\mathrm{B}>\overline{\mathrm{x}}$ & 10 & 14 & 24 \\
\hline & 30 & 30 & 60 \\
\hline $\mathrm{x}_{0}^{2}=2.665$ & & \\
$\mathrm{x}^{2}(\mathrm{n}=1,0.05)=3.841$
\end{tabular}

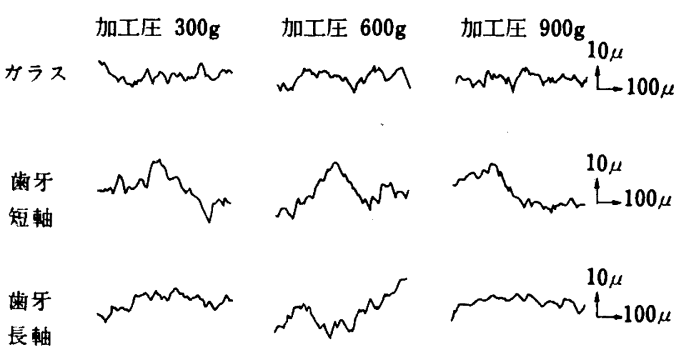

図 24

$2 \times 2$ 分割表を用いて， $x^{2}$ 検定を行つたところ， $x^{2}=2.665$ となり,この数值は $\mathrm{x}_{0}^{2}(\mathrm{n}=1,0.05)=3.841$ より小さ く, エナメル小柱長, 短軸走行方向間には, 加工速度に よる有意の差は認められない。

\section{4. 加工面の表面あらさについて}

一般に表面あらさは最大高さ，十点平均あらさおよび 中心線平均あらさで表示され, 日本工業規格では, 計測 面の基準長さを設定している．それによると最大高さの 䈖囲が $6.3 \mu$ から $25 \mu$ までのときは, 基準長さを $2.5 \mathrm{~mm}$ と規定されているが，この規定は工業製品の加 工精度の均一化のため存在すると思われる.

本加工においては振動子の径が $1.0 \mathrm{~mm}$ であるため, 日本工業規格で定める基準長さに足りないが，加工面の 状態を探る一つの方法として本計測法を用いた.

図 24 は加工圧 $300 \mathrm{~g}, 600 \mathrm{~g}, 900 \mathrm{~g}$ で加工した, ガラ ス，歯牙の加工面あらさの測定図である.

加工圧 $300 \mathrm{~g}, 600 \mathrm{~g}, 900 \mathrm{~g}$ における加工面について， 最大高さを計測すると，ガラスでは $11 \mu, 12 \mu, 13 \mu$, 歯牙のエナメル小柱長軸走行方向へ加工を行つたもの は, $12 \mu, 17 \mu, 13 \mu$, エナメル小柱短軸走行方向へ加 工を行つたものは $25 \mu, 27 \mu, 21 \mu$ であつた.

組成が均一であるガラスでは, 加工圧の違いによる加 工面のあらさにおよぼす影響がほとんど認められない．

一般に超音波加工では粗加工用に \#150 \#320 の䂠粒 が使用され，ガラス加工の際 \#320 の研粒で表面あらさ は約 $5 \mu$ といわれ，また砥粒の粒度と加工面のあらさは 
直線的な比例関係にあり，研粒の大きさが $40 \mu$ で最大 高さ $5 \mu, 80 \mu$ で約 $9 \mu, 110 \mu$ で約 $13 \mu$ であると報 告 ${ }^{26)}$ されてい.

歯牙の超音波加工における加工圧についての研究，報 告がないためその影響は明らかにされていない.エナメ ル小柱走行短軸方向へ加工を施こした場合, 長軸方向へ 加工を行つた時よりも，表面あらさの最大高さで約 2 倍 の值を示し，エナメル小柱走行の違いによる加工面への 影響があることが推測された。

従来回転工具を使用したエナメル小柱の異なる走行へ 研削を行つた研究では, 直角方向に研削したとき, エナ

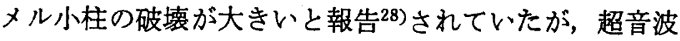
加工の場合も電子顕微鏡写真像, 表面あらさ等によりエ ナメル小柱走行への加工方向の違いによる加工面への影 響が明らかにされた。

エナメル小柱走行と砥粒の作用方向の関係が，歯質の クラックの発生状態に影響を及ぼすため, 菌牙を形成す るさいの最適研削方向, 条件などをさらに詳細にわたつ て検索する必要があると思われる.

稿を終るに臨み，終始ご懇篤なご指導とご校閲を賜わりまし た石岡 靖教授に深甚なる謝意を表します。

また種々ご援助下さいました本学小沢英浩教授，東京医科歯 科大学医用器材研究所加藤一男教授, 補緅学第一教室の諸先生 に嫨んで感謝の意を表します.

\section{文献}

1) Boyde, A. and Knight, P.J. : The Use of Scanning Electron Microscopy in Clinical Dental Research, Brit. dent. J. 127, $7: 313 \sim 322,1969$.

2) Seymour Hoffman, William S. Ewan, and Charles M. Drew : Scanning Electron Microscopy Studies of Dental Enamel, J. Dent. Res. 48, $2: 242 \sim 250$, 1969.

3）須賀昭一, 田熊庄三郎, 佐々木哲 : 歯の研究法, 構造と 組成, 東京, 1973, 医歯薬出版.

4) Ingraham, Rex and Tanner, E.E. : The adaptation of modern instruments and increased operating speeds to restrative procedures, J.A.D.A. $47: 311$ $\sim 323,1953$.

5）林都志夫, 他：油圧タービン式歯科用エンジンと高速切 削の臨床, 口病誌, 25, 1, 85 91, 1958.

6）増田泰二, 石岡 靖 : 歯牙の研削に関する研究, 口病 誌, 20, 1, 1953.

7）林都志夫, 他：ダイヤモンド・ポイントの粒度とエナメ
ル質研削能率との関係，口病誌，27，3，1960.

8）荒谷和明：研削による歯所の温度上年に関する研究，補 緅誌， 5, 1 16, 1961.

9) Peyton, F.A.: Temperature Rise and Cutting Efficiency of Rotating Instruments, New York D.J. 18, 1952.

10) Henry, E.E. and Peyton, F.A. : Vibration Characteristics of Rotating Dental Instrument, J. Dent. Res. 29, 1950.

11）石岡 靖：歯科用カーボランダム・ポイントの組成と研 削振動に関寸る実験的研究, 口病誌， $26 ， 2,408 \sim 428$, 1959.

12）藤田恒太郎: 歯の組織学, 東京, 1966, 医歯薬出版.

13) Gustafson, G. and Gustafson, A.G. : Human dental enamel in polarized light and contact microradiography, Acta, Odont. Scand. $19: 259,1961$.

14）今西市治, 他: エナメル質ことにエナメル小柱につい て, 阪大歯誌, 4, 1399, 1959.

15) Boyde, A. : The development of enamel structure, Proc. Roy. Soc. Med. $60: 923,1967$.

16）進 正密：ヒトの歯のエナメル兵の走査電子顕微鏡的観 察, 広大歯誌, 3, 115, 1971.

17) Mortimer, K.V. and Tranter, K.C. : Ultrastructure of Noncarious Enamel, J. Dent. Res. 50 : 1181, 1971.

18）本山佐太郎：人歯エナメル啠の小柱間質について，歯基 礎誌, 15, $31 \sim 50,1973$.

19) Seymour Hoffman, others: Scanning Electron Microscope Studies of EDTA-Treated Enamel, J. Dent. Res. 48 : 1234 1242, 1969.

20) Poole, D.F. and Johnson, N.W. : The effects of different demineralizing agents on human enamel surfaces studied by scanning electron microscopy, Archs. oral. Biol. $12: 1621 \sim 1634,1967$.

21) Johnson, N.W. : Factors affecting the differential dissolution of human enamel in acid and EDTA. A scanning electron microscope study, Archs. oral. Biol. $16: 385 \sim 396,1971$.

22）桐野忠大，他：ヒトエナメル質の粠造に関する走査型電 子䫓微鏡的研究, 口病誌, 39, 3, 1972.

23）诋粒加工研究会編：砥粒加工技術便覧, 東京, 1965, 日 刊工業新閶社.

24）加藤仁市, 平野秀利, 石岡 靖: 歯牙エナメル犋の被削 性に関する研究，第 1 報 超音波加工法による検討，補 緅誌, 17, 1, 1973

25）塩川延洋, 安田克広 : エアタービンによる高速歯科切削 の研究 (第 1 報), 歯理工誌, 4, 7, 1963.

26）島川正憲：超音波加工，七ラミックス，3，5，339 348, 1968.

27）島川正憲：強力超音波応用，東京，1970，日刊工業新閶 社.

28）加藤一男, 他 : エナメル兵の結晶配向と研削に関する研 究, 医器材, 2, 25 39, 1968. 


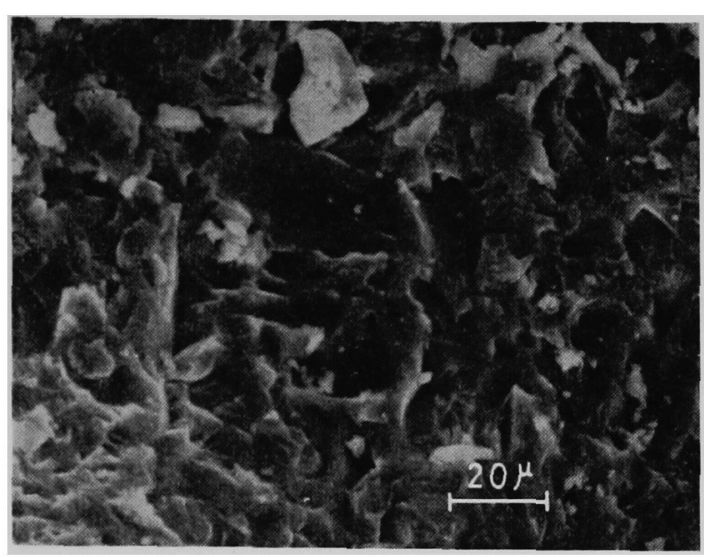

図 1

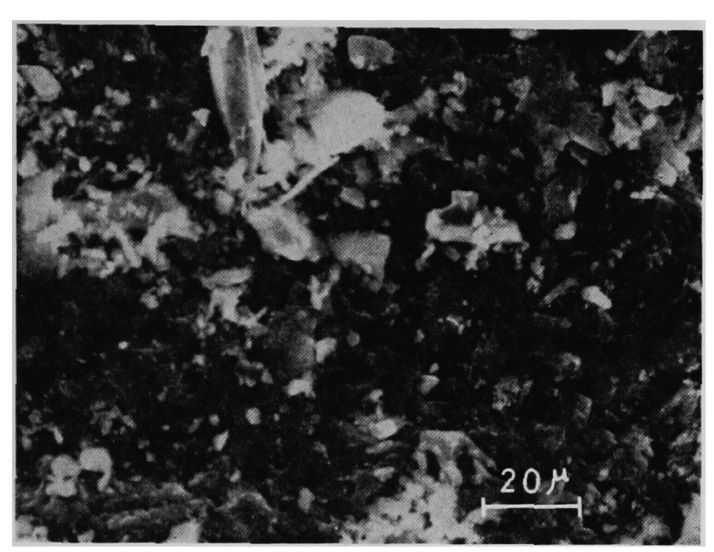

图 3

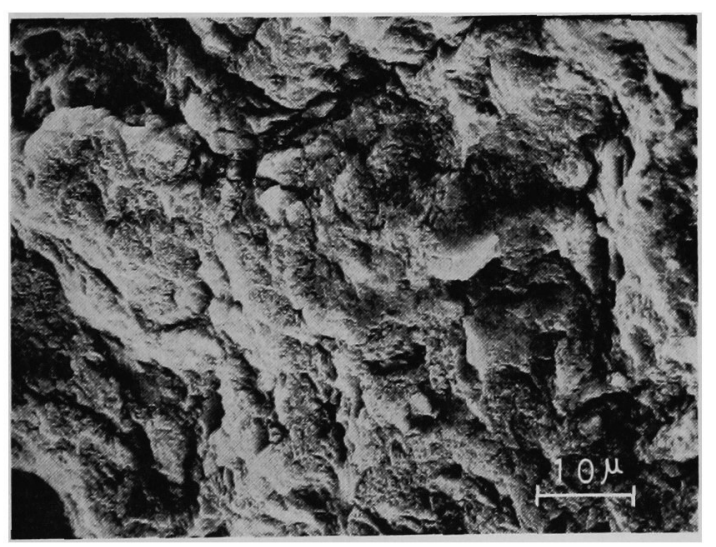

図 5

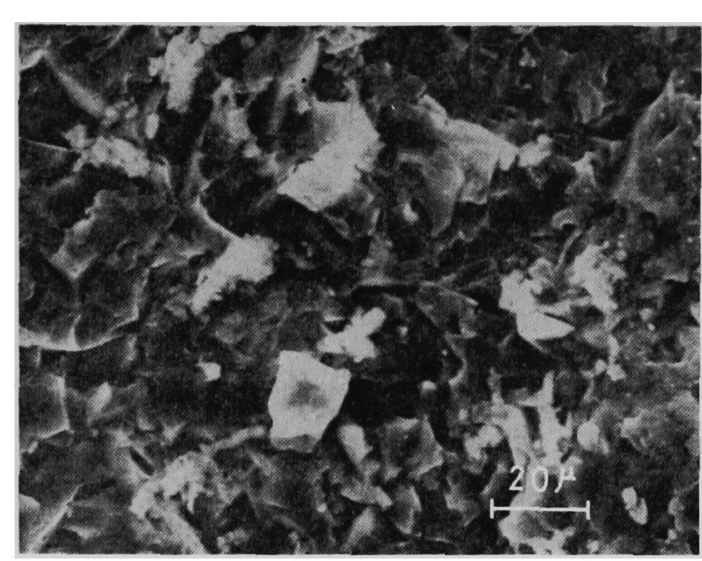

図 2

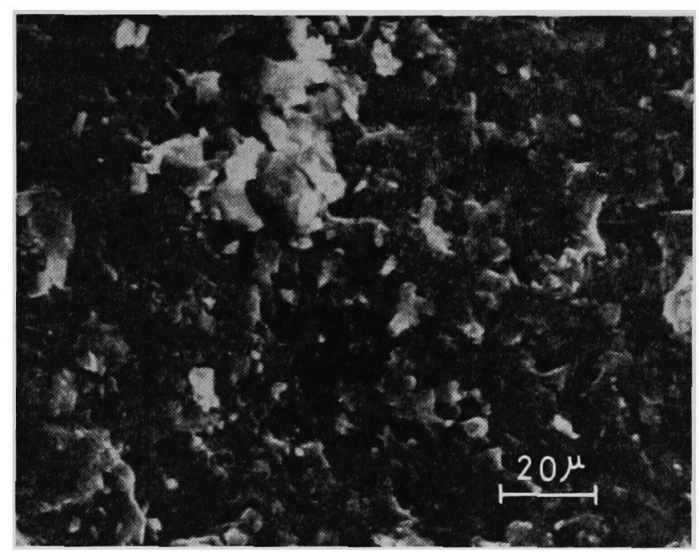

図 4

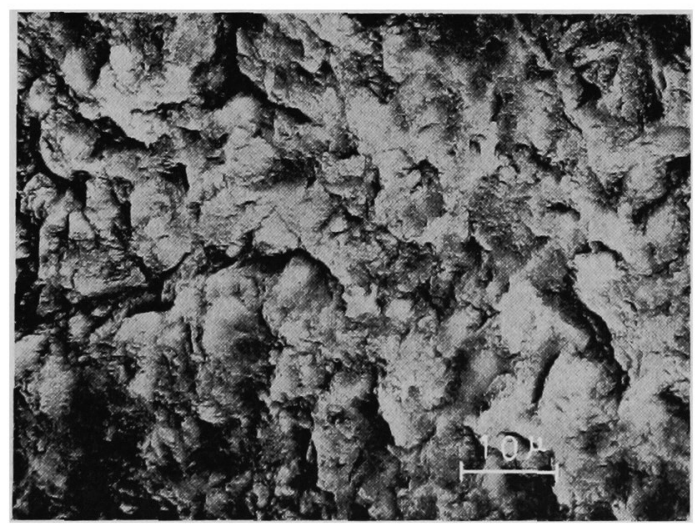

図 6 


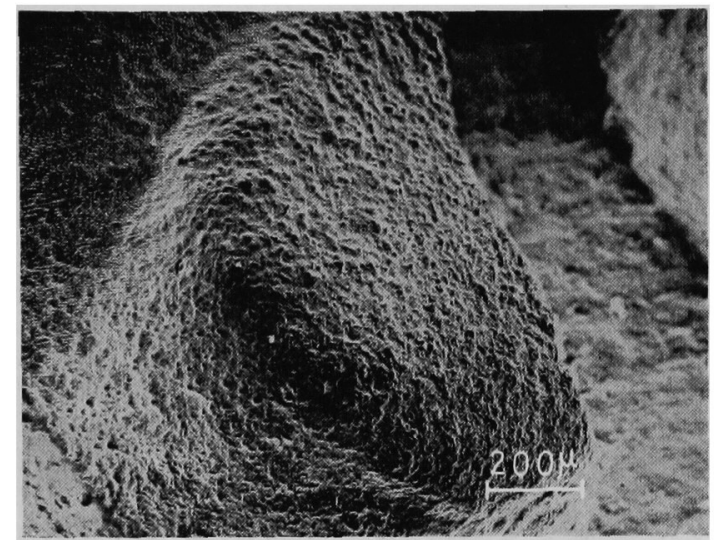

図 7

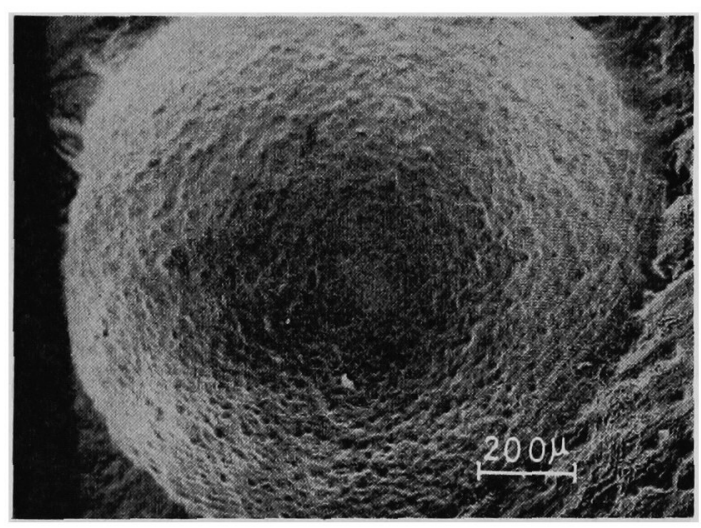

图 9

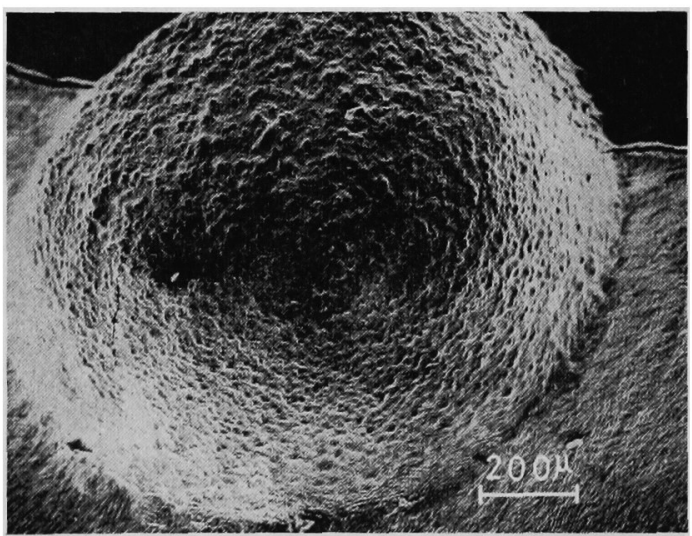

図 11

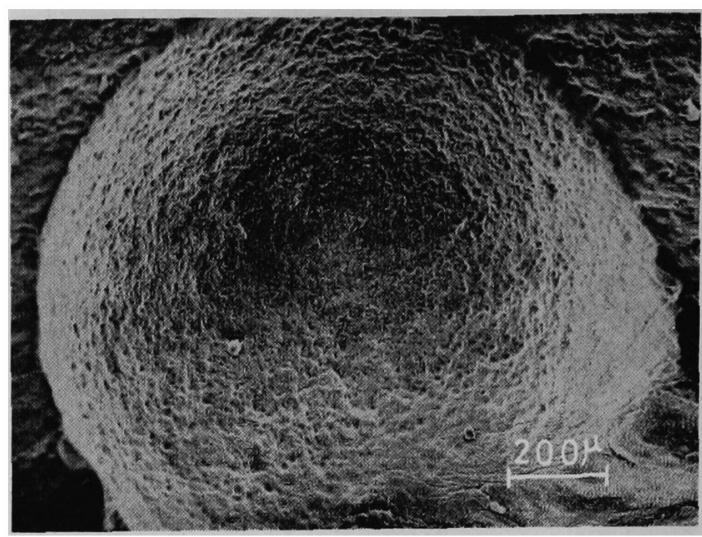

図 8

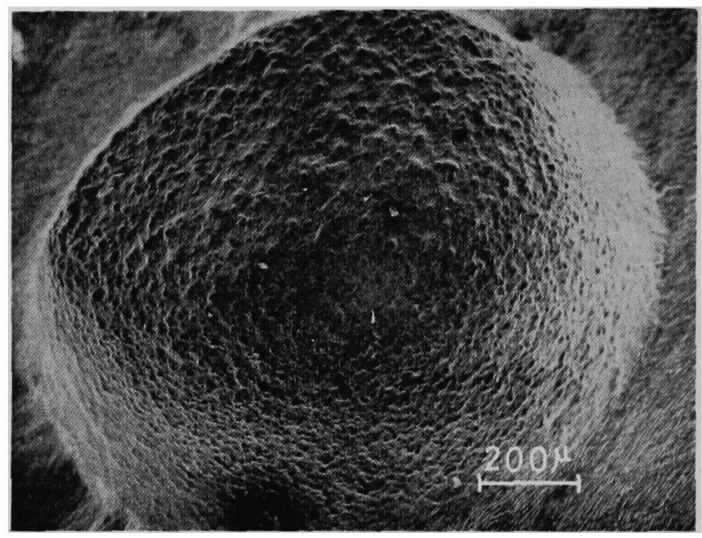

図 10

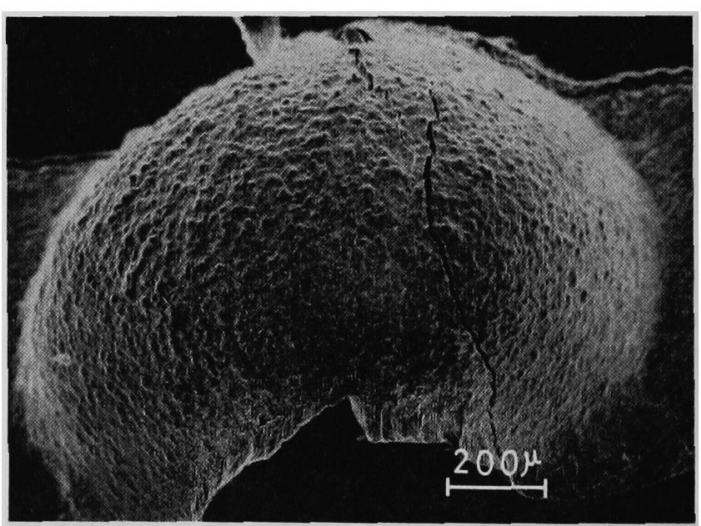

図 12 


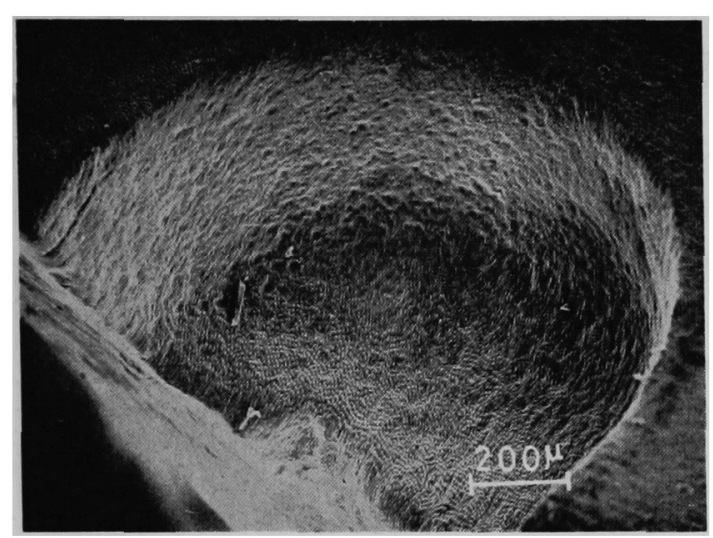

図 13

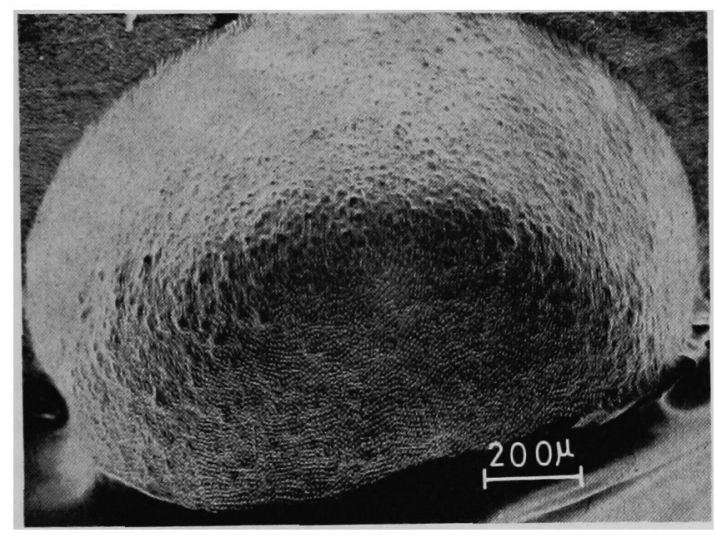

図 15

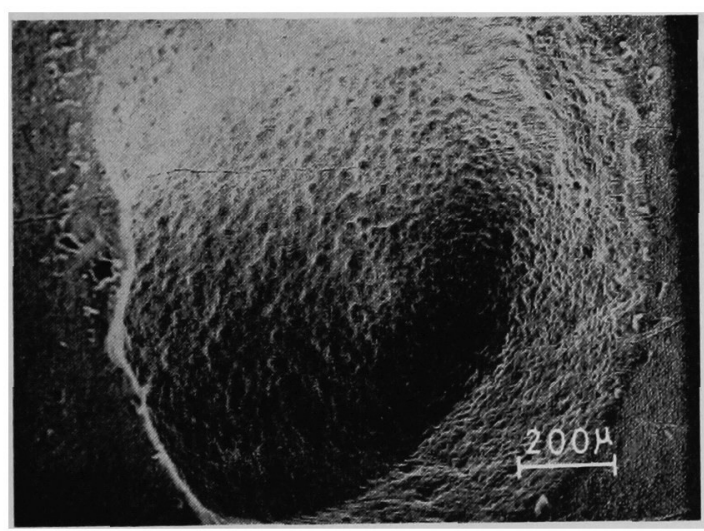

図 17

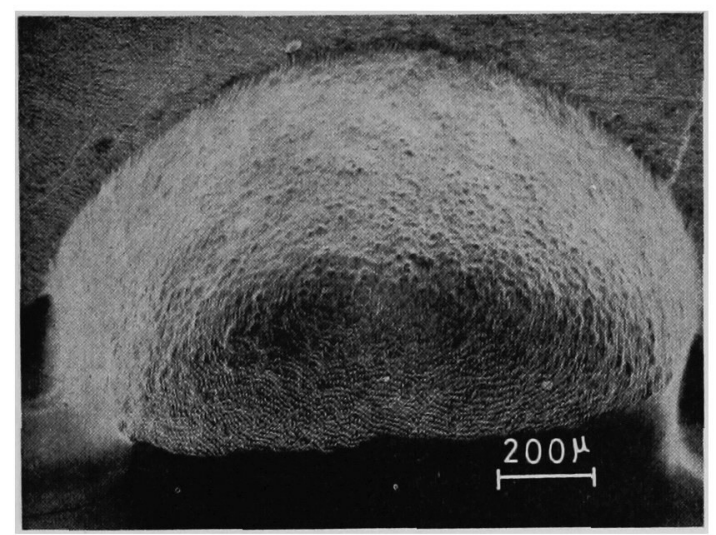

図 14

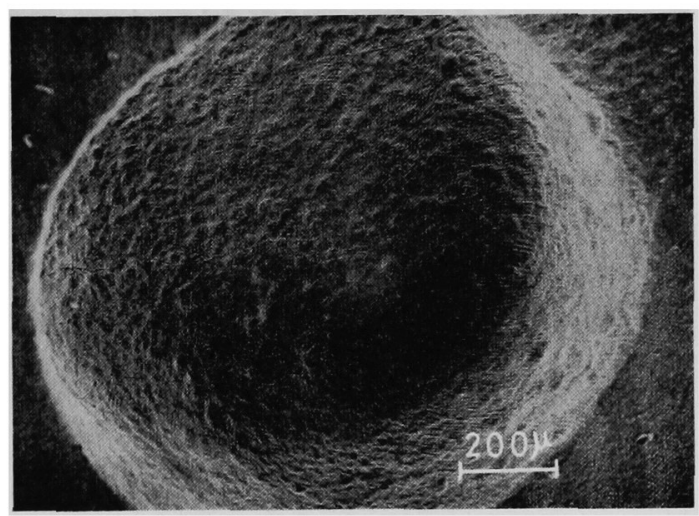

図 16

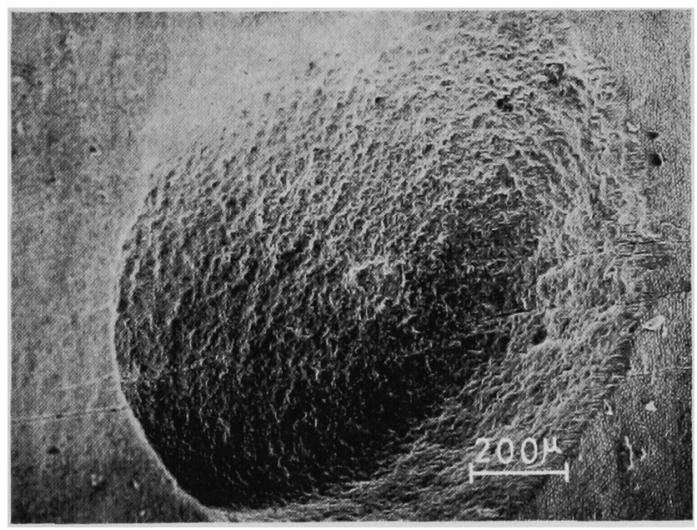

図 18 


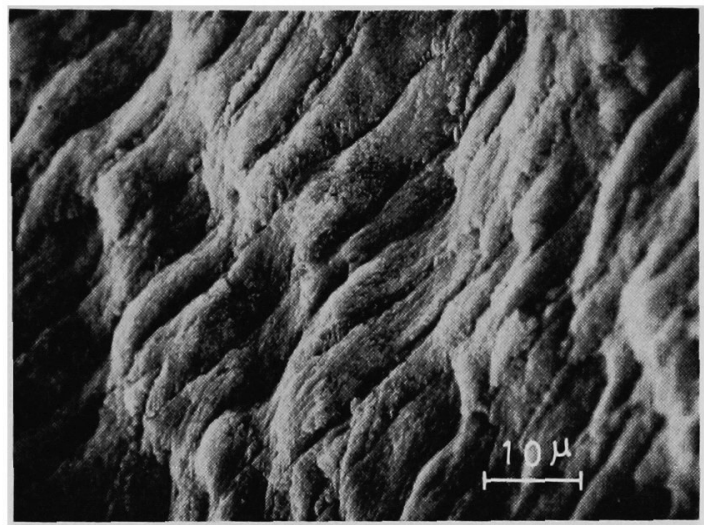

図 19

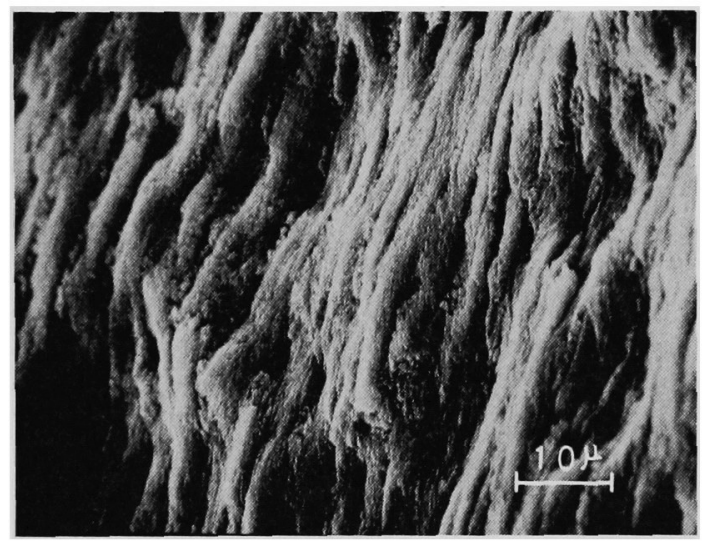

図 21

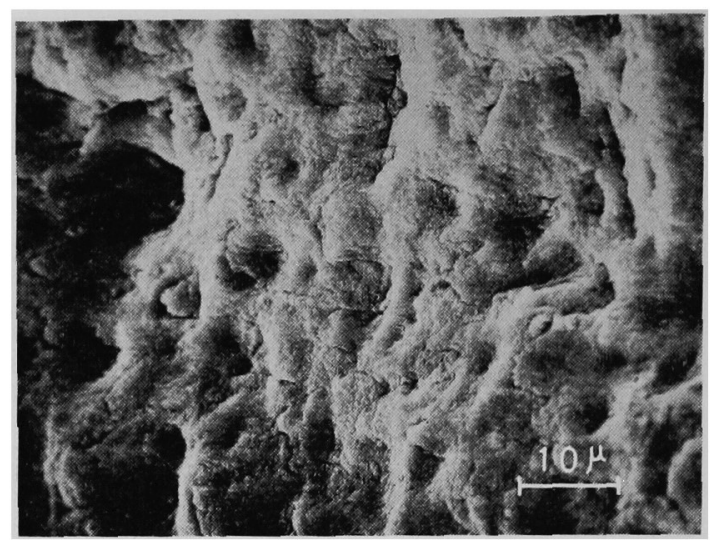

図 20

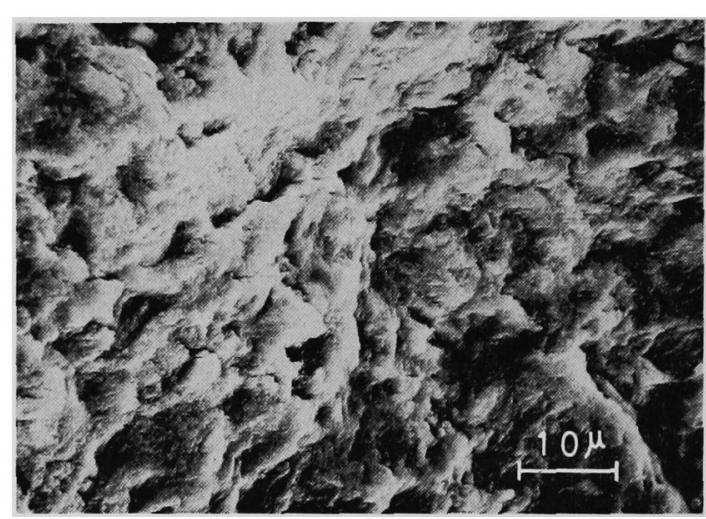

図 22
$<$ 図説明 $>$
図 1 4 ガラス加工面 $\times 1,000$
図 5,6 歯牙加工面 $\times 2,000$
図 7 18 歯牙加工面 $\times 100$
図 19 21 齒牙加工面 $\times 2,000$ 